\title{
TEACHING PHYSICS AT A MEDICAL UNIVERSITY: PROBLEMS AND APPROACHES TO SOLUTION
}

\section{Lola Khamidovna Zoirova}

Candidate Of Physical And Mathematical Sciences, Associate Professor, Department "General Physics" Navoi State Mining Institute, Navoi City, Republic Of Uzbekistan

\section{Malika Sherali Kizi Tukhtamishova}

Student, Faculty Of Energy And Mechanics, Navoi State Mining Institute, Navoi City, Republic Of Uzbekistan

\author{
Nafosat Nizomitdin Kizi Sultonova
}

Student, Faculty Of Energy And Mechanics, Navoi State Mining Institute, Navoi City, Republic Of Uzbekistan

\section{ABSTRACT}

The process of teaching physics at a medical university is developing within the framework of a fairly rigid modern educational paradigm. On the one hand, there is a steady reduction in the study time allotted to the academic discipline, both lecture hours and hours of practical training. On the other hand, the role and place of physics as the basis of radiation medicine in the health care system, and specifically in medical diagnostics, is constantly growing. In addition, modern physics, following in the wake of the advanced achievements of science and technology, is actively replenished with new technologies and teaching methods, which leads to a significant increase in the material required for assimilation. There is no doubt that this problem is not specific to physics and therefore its solution is not in the plane of increasing the volume of hours at the expense of other disciplines. Innovative approaches are required that take into account modern realities and general trends in the development of the educational process.

KEYWORDS:- Healthcare, algorithm and technology of teaching physics, radiation medicine, medicalphysical complexes, medical physics, physical and technical support, modern requirements of higher medical education, training system for the future physicist-physician.

\section{INTRODUCTION}

One of the conditions of the new approach is the orientation of the educational process to a greater extent on learning, which presupposes serious systemic changes in the organization and construction of education: reorientation from "input indicators" (terms of training, content, goals) to results presented in the form of competencies; the growing role of academic and professional recognition with the necessary changes in the content of training and assessment technologies for the ability to quickly navigate in the rapid flow of scientific information.

An analysis of the programs that exist today shows that there is no specific purposeful algorithm in teaching these disciplines in different departments and in different periods of study in the medical universities of the Republic of Uzbekistan. One can give an example of the 
CURRENT RESEARCH JOURNAL OF PEDAGOGICS 2(6): 171-173, June

2021 DOI: https://doi.org/10.37547/pedagogics-crjp-02-06-32

ISSN 2767-3278

(C)2021 Master Journals

\section{Crossref do) 81 Google}

Accepted 25thJune, 2021 \& Published 30 th June, 2021

period of liquidation of the Chernobyl accident and its consequences, where it was doctors who became the main source of the spread of radiophobia among the population. Hence, it becomes obvious that the exemplary program and curriculum for the discipline "Radiation Medicine" must meet the modern requirements of higher medical education, including taking into account the construction of a nuclear power plant (NPP) in Uzbekistan.

Radiation medicine requires specialists from a wide range of professional knowledge and skills, skills, a certain set of general cultural values, flexibility of thinking, and the ability to apply them in work.

\section{MaIn PART}

Of course, the majority of physicists have been engaged in the development of physics for many decades as the fundamental basis of modern natural science. Gradually, physics, in addition to this, began to more and more solve the problems of applying physical laws, processes, means and technologies to various areas of human activity, primarily to technology and weapons. Today the situation has changed, and physics is shifting its priorities towards peaceful purposes, including healthcare. Currently, traditional medicine is increasingly turning into physical medicine, equipped with the most complex, expensive and at the same time very effective medical and physical complexes and technologies.

The main feature of modern medicine is its high physical and technical equipment. At the same time, the most important weapons of physicians in the fight against diseases are precisely various medical and physical technologies of the highest level and radiological devices for diagnostic and therapeutic purposes, which greatly increase the possibilities of medicine. At present, it is difficult to imagine any problem of prevention, diagnosis or treatment, where the achievements of physics, primarily the physics of ionizing radiation, would not be used, and medical radiology is entirely based on the achievements of modern medical physics.

\section{Material Method}

At present, of all sections of the $\mathrm{MF}$, radiation medical physics has received the greatest development. It is at least $80 \%$ in terms of the volume of work and the number of specialists from all foreign and domestic MF, "serving" medical and diagnostic technologies based on the use of ionizing radiation. These are mainly radiation therapy, nuclear medicine, and X-ray studies. In turn, in clinical conditions, the main purpose of the radiation MF is the physical and technical support of therapeutic radiation oncology (radiation therapy). It is generally accepted that one of the serious flaws in the system of professional training of a specialist is insufficiently purposeful, consistent and poorly controlled education of students' creative activity and independence. The most important condition that contributes to the formation of these qualities of the personality of future specialists is the construction of the educational process on the basis of the widespread introduction of problem and heuristic training, through a system for finding solutions by students of educational and practical problems. In our opinion, the implementation of the principle of linking education with practical activity is possible in the process of teaching practical physics at the main graduating departments of the university (biophysics, radiology, radiation medicine, etc.). Unfortunately, the curricula in these disciplines, even if they contain physical sections, are not sufficiently developed. In our opinion, the most justified is either the creation of optional physics courses in the most relevant areas of medicine for 5-6 year students or even short cycles in practical physics for graduating departments 
CURRENT RESEARCH JOURNAL OF PEDAGOGICS 2(6): 171-173, June

2021 DOI: https://doi.org/10.37547/pedagogics-crjp-02-06-32

ISSN 2767-3278

(C)2021 Master Journals

\section{Crossref do) 81 Google}

Accepted 25thJune, 2021 \& Published 30 th June, 2021

with the involvement of physics teachers. The most important aspect of modern teaching is an adequate system for assessing student knowledge. We believe that the point-rating (credit-modular) system used at the departments is most conducive to stimulating and improving the quality of students' educational activities.

Teaching a future specialist to independently acquire and constantly deepen his knowledge, to form persistent cognitive motives and the ability to quickly navigate in the rapid flow of scientific information is one of the main tasks of modern education. Self-education and self-study should become two interrelated aspects of the pedagogical process.

\section{Conclusion}

Thus, the modern MF is engaged in the study of systems consisting of physical radiation, the human body and its diseases, medical and diagnostic devices, drugs, materials and technologies, as well as the use of physical radiation and devices for the prevention and diagnosis of diseases, for the treatment of patients using methods and the means of physics, mathematics and technology.

Summarizing the above, we can conclude that the radiation physics training system is far from perfect. Certain problems have accumulated in it, the solution of which will largely depend on the implementation of modern ideas for the further development of the discipline. The main task in this matter is to comprehend and build a rational relationship between the trends in the development of physics and the training system of the future physicist-physicist.

\section{ReFERENCES}

1. Stozharov A.N. Radiation medicine. Study guide. Third edition. Minsk, 2007. -P. 75-78.

2. Kudryashov Yu.B., Berenfeld B.S. Radiation biophysics. M., 1979. -P. 52-58.

3. Stozharov A.N. Radiation medical physics. Textbook / A.N. Stozharov. - Minsk: Higher. shk., 2007 . -P. 369.

4. Shatravko N.S. Active teaching methods as a factor in the formation of innovative pedagogical activity of teachers / N.S. Shatravko // Prospects for the development of higher education: Proceedings of the 2 nd Intern. scientific-method, conf. - Grodno: GGAU, 2009 . -P. 127-131.

5. Tereshko T.A. Innovative education in higher education / T.A. Tereshko // Training of highly qualified scientific personnel in the context of innovative development of society: Proceedings of the Intern. scientificpractical. conf. - Minsk: GU "BelISA", 2009. P. 242-244.

6. Nechaeva V.G., Shevchenko E.V., Voronova L.K., Korzhuev A.V. Teaching physics at a medical University: history and modernity. Siberian medical journal. No.7, 2010. -P. 3639.

7. Chernyaev A.P., Kolyvanova M.A., Borshegovskaya P.Yu. Radiation technologies in medicine. Medical accelerators. // VMU. Series 3. Physics. Astronomy. No. 6, 2015. -P. 28-36.

8. Kostylev V.A., Narkevich B.Ya. Radiation medical physics - the fundamental basis of medical radiology / V.A. Kostylev, B.Ya. Narkevich // Russian Cancer Research Center. N.N. Blokhin Russian Academy of Medical Sciences. - Moscow. Radiology and Practice. No. 2, 2007. -P. 42-52. 